\title{
The Contribution of Management Control Systems to Environmental Capabilities
}

\section{Elisabeth Albertini}

\section{Journal of Business Ethics}

ISSN 0167-4544

J Bus Ethics

DOI 10.1007/s10551-018-3810-9

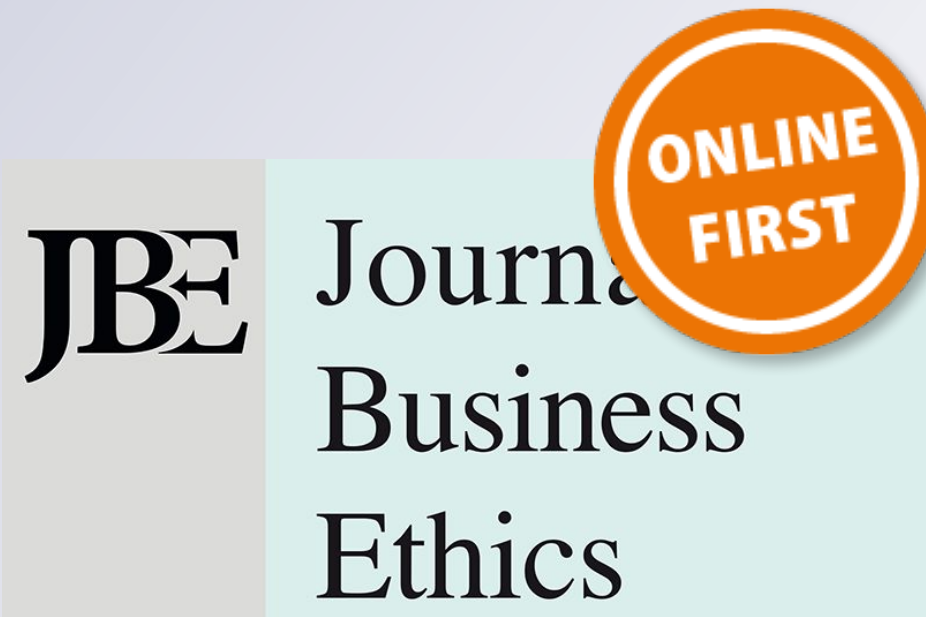

Volume 139, No. 1
November (II) 2016

Editors in Chief: :
R.Edward Freeman
Michelle Greenwood

EDITORIAL

Enhancing the Impact of Cross-Sector
Partnerships - Four Impact Loops for Partnerships - Four Impact Loops for Channeling Partnership Studies
R. van Tulder $\cdot$ M.M. Seitanidi $\cdot$ A. Cran R. van Tulder ' 1
S. Brammer 1

SPECIAL SECTION ARTICLES Microfoundations of Partnerships: Exploring the Role
Trickle Effects A. Kolk · M. Vock · W. van Dolen 19 Cross-Sector Partnerships and the Co-creation of Dynamic Capabilities for Stakeholder Orientation

Configuration and Development Corte A Companson Partinestors R. Gutiérrez - P. Márquez - E. Reficco 55 Scrutinizing Public-Private Partnerships for Development: Towards a Broad Evaluation Conception L. Stadtler 71

ORIGINAL PAPER

The Moderating Effect of Supervisor's Behavioral Integrity on the Relationship between Regulatory Focus and

Impression Management

K. Michele Kacmar - R. Tucker 87

Springer 
Your article is protected by copyright and all rights are held exclusively by Springer Science+Business Media B.V., part of Springer Nature. This e-offprint is for personal use only and shall not be self-archived in electronic repositories. If you wish to self-archive your article, please use the accepted manuscript version for posting on your own website. You may further deposit the accepted manuscript version in any repository, provided it is only made publicly available 12 months after official publication or later and provided acknowledgement is given to the original source of publication and a link is inserted to the published article on Springer's website. The link must be accompanied by the following text: "The final publication is available at link.springer.com". 


\title{
The Contribution of Management Control Systems to Environmental Capabilities
}

\author{
Elisabeth Albertini ${ }^{1}$ \\ Received: 25 March 2017 / Accepted: 5 February 2018 \\ (C) Springer Science+Business Media B.V., part of Springer Nature 2018
}

\begin{abstract}
A growing number of companies are implementing proactive environmental strategies with the objective of gaining competitive advantage through an enhanced reputation, the reduction in production costs, and a first-mover advantage in the green product market. Yet according to the natural-resource-based view, the development and maintenance of unique and valuable environmental capabilities are the central elements allowing companies to gain financial benefit from their proactive environmental strategy. In this context, management control systems can contribute to the development of environmental capabilities by focusing attention on strategic priorities and stimulating dialogue. Through a single case study, and building on Simons' (Levers of control: how Managers use innovative control systems to drive strategic renewal, Harvard Business School Press, Boston, 1995) four levers of control, we propose a conceptual framework of management control levers that show how companies can enhance (1) stakeholder integration capability through the joint use of belief, boundary, and diagnostic control systems; (2) shared vision capability through the joint use of the belief and boundary systems; (3) organizational learning capability through the use of interactive control systems and to a lesser extent diagnostic control systems; and (4) continuous innovation capability through the use of interactive control systems, belief systems and to a lesser extent diagnostic control systems.
\end{abstract}

Keywords Proactive environmental strategy $\cdot$ Natural-resource-based view $\cdot$ Management control systems

\section{Introduction}

The environment has been identified as a major issue that the academic business ethics community believes it will face in the coming decades (Holland and Albrecht 2013). Indeed, from the mid-1990s, the yearly United Nations Climate Change Conferences, better known as Conference of the Parties (COP) assess progress in dealing with climate through formal meetings. These conferences have led to significant commitments such as the negotiation of the Protocol of Kyoto in 1995 and more recently, the Paris Agreement in 2015. In that context, companies are increasingly asked to manage the ethical implications of the issues of climate change (Chang 2011). As a result, societal pressure demanding that companies take responsibility for the risk of global warning is, first and foremost, ethical in nature

Elisabeth Albertini

albertini.iae@univ-paris1.fr; ealbertini2a@gmail.com

1 IAE-Sorbonne Business School, 8 bis rue de la Croix Jarry, 75013 Paris, France
(Besio and Pronzini 2014). In that context, a growing number of companies have implemented practices such as formal ethics systems, corporate codes and participation in initiatives to shape ethical standards or behavior to address the environmental issue (Delgado-Ceballos et al. 2012; Dhanda and Hartman 2011). Yet, many managers still believe that protecting natural environment is a cost that erodes corporate financial performance. These managers do not consider proactive environmental management as contributing to organizational survivability (Dibrell et al. 2015). However, it appears that corporate businesses will be significantly constrained by and dependent upon ecosystems and natural environment in the future. In other words, it is likely that environmental strategy and competitive advantage in the coming years will be rooted in capabilities that facilitate environmentally sustainable economic activity (Hart 1995; Hart and Dowell 2011). This perspective has motivated researchers to identify key environmental capabilities that support environmental and financial performance (AragonCorrea and Sharma 2003; Sharma et al. 2007). 
According to the natural-resource-based view (NRBV) of the firm (Aragon-Correa and Sharma 2003; Hart 1995; Hart and Dowell 2011), only firms with specific environmental capabilities such as stakeholder integration, organizational learning, continuous innovation, and shared vision can realize financial benefits from a proactive environmental strategy (L. C. Leonidou et al. 2017; Sharma et al. 2007; Sharma and Vredenburg 1998). Moreover, firms that interpret their approach to environmental challenges from an ethical perspective are likely to be more proactive to find solutions, forward-looking, and less concerned with stopping at legal compliance (Besio and Pronzini 2014; Haney 2017).

In that context, management control systems and the joint use of the four levers of control-belief systems, boundary systems, diagnostic control systems (DCS), and interactive control systems (ICS)—proposed by Simons (1990, 1995), can contribute to the development of firms' environmental capabilities by focusing attention on strategic priorities and stimulating dialogue (Arjaliès and Mundy 2013; Henri 2006; Journeault 2016).

Although the literature suggests that the development of particular capabilities can contribute simultaneously to environmental and economic performance, little research has explored this implication (Journeault et al. 2016). More importantly, little attention has been devoted to identifying the genesis of environmental capabilities (Hart and Dowell 2011). This paper aims to enhance understanding of these issues by exploring "how a company can use the four levers of control to enhance its environmental capabilities and ensure they contribute to competitive advantage?". This cross-disciplinary study contributes to both the management control and NRBV literature by proposing a conceptual framework of management control levers that show how companies can enhance (1) stakeholder integration capability through the joint use of belief systems, boundary systems, and DCS; (2) shared vision capability through the joint use of belief and boundary systems; (3) organizational learning capability through the joint use of ICS and (to a lesser extent) DCS; and (4) continuous innovation capability through the use of ICS, belief systems, and (to a lesser extent) DCS. This study addresses recent calls in the environmental management literature for qualitative research about the influence of MCS on organizational capabilities (Hart and Dowell 2011; L. C. Leonidou et al. 2017; LopezGamero et al. 2008), and in the management control literature for a better understanding of the dynamic relationships between NRBV strategy and organizational capabilities (Henri 2006; Journeault 2016). From a managerial perspective, the conceptual framework details more explicitly the relations between the different levers of control and environmental capabilities, so that companies can realize financial benefits from their proactive environmental strategy.
The remainder of the paper is organized as follows. In the next section, we review the background literature on proactive environmental strategy and Simons' (1995) levers of control framework. This is followed by a description of our research design, including the methods used to conduct the study. We then present and discuss the study's findings. Finally, we conclude and outline directions for further research.

\section{Theoretical Background}

\section{Proactive Environmental Strategy}

At a corporate level, a proactive environmental strategy, defined as an environmentally oriented strategy, supported by top management, that focuses on the prevention of waste, emissions and pollution through continuous learning, total quality environmental management, risk-taking and planning (Menguc et al. 2010), is affected by increasing public concern regarding the ethical issue of the climate change and regulatory forces (Banerjee et al. 2003). Indeed, external factors, such as environmental legislation, environmental movements (e.g., consumerism, environmentalism), or pressures exerted by competitors or stakeholders influence the firm's environmental behavior (Boiral 2007; Darnall et al. 2008; Williamson et al. 2006).

At a functional level, R\&D plays a decisive role in identifying technologies to produce goods that minimize negative ecological impact (Shrivastava 1995), enhance energy conservation (Cordano et al. 2010), or reduce carbon emission reduction (Revell et al. 2010). In that context, proactive environmental strategy depends on the supportive role of top management in encouraging innovative environmental actions by employees (Ramus and Steger 2000) and the marketing focus on the commercialization of the green products of the companies (L. C. Leonidou et al. 2017).

According to the NRBV, a proactive environmental strategy is an extensive source of competitive advantage in terms of increasing awareness of constraints imposed by the natural environment (Hart 1995; Hart and Dowell 2011). Academic research has distinguished between lowcost advantages and differentiation advantages (Shrivastava 1995). Companies can realize significant savings that result in a cost advantage relative to competitors through pollution prevention; this not only saves the cost of installing and operating end-of-pipe pollution control devices, but also increases productivity and efficiency (Dowell et al. 2000; Hart and Ahuja 1996). Since pollution is a sign that resources have been used inadequately, inefficiently, or ineffectively during the manufacturing process, it appears that less pollution means better use of inputs, resulting in lower raw material and waste disposal costs (Lanoie et al. 2011; 
Porter and van der Linde 1995). Furthermore, pollution prevention has the potential to bring emissions well below required levels, reducing the firm's compliance and liability costs (Worthington and Patton 2005). Finally, the combination of end-of-pipe and pollution prevention technologies can be used to evaluate the advantages of viewing ethics as drivers for the long-term sustainability of a business (LopezGamero et al. 2008). The differentiation advantage is gained through green product stewardship that extends the scope of pollution prevention, ensuring that environmental concerns are integrated into product design and manufacturing processes (Dangelico and Pujari 2010). This can be achieved by gaining preferred or exclusive access to important, but limited, resources or by establishing rules, regulations, or standards that are uniquely tailored to the firm's capabilities (Aragon-Correa et al. 2008). While the green product stewardship strategy focuses on incremental improvements to current products and processes, the clean technology strategy focuses on future technologies and markets (Hart and Dowell 2011). Companies can gain a differentiation advantage through the development of their organizational capacity to innovate permanently in the specific field of clean technology (Dangelico and Pujari 2010).

In this context, organizational resources, especially physical, technical, and reputational resources, are vital to gaining these competitive advantages (Aragon-Correa and Sharma 2003; C. N. Leonidou and Leonidou 2011; Revell et al. 2010). More importantly, the NRBV posits that financial benefits gained from a proactive environmental strategy are an outcome of some environmental capabilities, such as stakeholder integration, ongoing learning and continuous innovation and shared vision associated with a proactive environmental strategy (Alt et al. 2015; Hart 1995; Journeault 2016). Indeed, a proactive environmental strategy is built through a path-dependent process of integrating a firm's environmental capabilities and is therefore non-replicable or inimitable (Hart and Dowell 2011; Hoffman et al. 2012; Sharma et al. 2007).

Stakeholder integration, defined as the ability to establish trust-based collaborative relationships with a wide variety of stakeholders (Sharma and Vredenburg 1998), helps companies to develop a more proactive environmental approach, since they have to collaborate with a wide variety of social, environmental, and economic stakeholders in findings solutions to environmental problems (Sharma et al. 2007). Shared vision among employees and managers, providing norms for behaviors and corporate environmental ethics, can also intensify the extent to which environmental strategies lead to competitive advantage (Alt et al. 2015; Lannelongue et al. 2014; Lopez-Gamero et al. 2008). Continuous innovation, defined as the capability to create new environmental ideas, products, and processes, involves the firm's ability to initiate strategic environmental changes in its policies and activities, allowing it to remain a step ahead of its competitors (Journeault 2016). Moreover, green product and process innovation is positively related to corporate environmental ethics that positively affects corporate competitive advantage (Chang 2011). Organizational learning refers to the development of ecological and ethical insight and its association with past and future ecological actions, as well as their effectiveness (Kloot 1997). By developing a path-dependent process of detecting ecological problems and opportunities within the organization, and between the organization and its changing environment, organizational learning is recognized as a capability that is difficult to imitate or substitute and that contributes to developing a sustainable competitive advantage (J. F. Henri and Journeault 2010).

However, little attention has been paid to identifying the genesis of these capabilities (Hart and Dowell 2011). This study attempts to bridge the gap between the NRBV and MCS literatures by studying how a company can use the four levers of control to enhance its environmental capabilities, which in turn can contribute to competitive advantage.

\section{Management Control Systems as a Means of Developing Environmental Capabilities}

MCS are defined as a package of formal, information-based routines and procedures that managers use to maintain or alter patterns in organizational activities (Simons 2000). Financial and non-financial information is produced for the purpose of making decisions, monitoring the achievement of plans and goals, communicating corporate strategy internally, influencing the strategy-making process, supporting organizational learning, and producing external reports (Gond et al. 2012; Lueg and Radlach 2016; Tucker et al. 2009).

Simons' framework (1995) describes four levers of control that help an organization implement its strategy successfully: belief systems, boundary systems, diagnostic control systems (DCS), and interactive control systems (ICS). The full potential of the four levers of control is realized when they are mobilized together so that they can facilitate the implementation and attainment of a company's strategic objectives (Arjaliès and Mundy 2013; Lisi 2015).

Belief systems are used by managers to define, communicate, and reinforce the core values, purpose, and direction of the organization (Ahrens and Chapman 2004). Belief systems help to foster a sense of stability and continuity but can also enable organizational change when managers use them to introduce new priorities or values (Bruining et al. 2004). Within the context of proactive environmental strategy, belief systems are used to establish commitment to agreed environmental plans through a code of conduct or code of ethics and to motivate employees to implement environmental activities (Arjaliès and Mundy 2013). Indeed, 
in decision-making processes, the presence of these code of ethics is intended to foster moral judgments based on the values they contain (Besio and Pronzini 2014). Belief systems are also used to enhance the managerial perception of ethics within the organization, insisting on the application of moral principles when making business decisions (Lopez-Gamero et al. 2008). Indeed, the role of management is crucial in establishing a company's ethical norms and expectations (Chang 2011).

Top managers use boundary systems to establish specific limits and rules that must be respected. The boundary lever of control is represented by an explicit set of organizational definitions and parameters, commonly expressed in negative or minimum terms (Simons 1995). Managers use strategic boundaries to communicate to employees activities that are considered acceptable or off-limits to ensure that employees do not waste the organization's resources (Arjaliès and Mundy 2013). In the context of proactive environmental strategy, legal or voluntary standards form strategic boundaries that can be regulative (i.e., coerced, such as local laws limiting air, water, or soil pollution); normative (prescriptively imposed through accreditation or certification, such as ISO 14001 or the Global Reporting Initiative); or culturalcognitive (mimetic common beliefs, customs, and logic of action such as adhesion to the United Nations Global Compact) (Scott 2001).

Diagnostic control systems (DCS) are formal feedback systems used to monitor organizational outcomes and to correct deviations from preset standards of performance. Progress on strategic initiatives is evaluated against performance measures that incorporate a combination of short-term and long-term measures, information on performance against key financial and non-financial objectives, and comparative data on competitors (Lisi 2015; Nilsson 2002). In the context of environmental strategy, managers can use DCS to compare the environmental performance of the company against both internally or externally derived targets through reporting frameworks such as the green house gas emission dashboard (Arjaliès and Mundy 2013; Journeault 2016).

Interactive control systems (ICS) are formal systems used by top managers to involve themselves regularly and personally in subordinates' decision making. The purpose of making a control system interactive is to focus attention and force dialogue and learning throughout the organization (Bisbe and Otley 2004). Managers use ICS to facilitate the debate about the underlying action plans that drive an organization's activities and to obtain access to local knowledge about strategic uncertainties that can be used to develop strategic plans (Bedford 2015; Shapiro 2016). When applied to the management of environmental strategy, interactive processes can refer to frequent meetings between top managers and the environmental committee that stimulate environmental innovation either during the manufacturing process or in green products (Perez et al. 2007). The interactive use of MCS can trigger organizational learning processes and changes that can enhance environmental performance (Shapiro 2016). The involvement of external stakeholders in these formal meetings can provide an alternative source of information about the direction of environmental strategy (Arjaliès and Mundy 2013). Moreover, managers use ICS as a communication process that enables operational managers, employees, and external stakeholders to share information and ideas (Lisi 2015).

The application of the four levers of control (Simons 1995) provides a useful framework that can allow the development of environmental capabilities that provide competitive advantages. Indeed, the joint uses of the four levers of control allow the integration of sustainability values within organizational strategy (Gond et al. 2012) and substantially influence employees' ethical reasoning processes (Goebel and WeiBenberger 2017). Simons suggests bidirectional relations between interactive and belief systems on the one hand, and boundary and diagnostic systems on the other. Indeed, interactive/belief systems empower organizational learning, create positive and inspirational forces, and provide employees guidance and motivation (Journeault et al. 2016), while boundary/diagnostic systems constrain and ensure compliance with internal or external targets (Bedford 2015; Simons 2000). Diagnostic and belief systems foster organizational learning, while interactive systems enhance the relationship between innovation and performance in the long term (Bisbe and Malagueno 2009; Shapiro 2016).

In this context, it seems that the different levers of control can enhance the development of a company's environmental capabilities. We investigate this through a single case study.

\section{Research Methodology}

To address our research question that is "How can a company use the four levers of control to enhance its environmental capabilities and ensure they contribute to competitive advantage?", we adopted a qualitative methodology based on a single case study (Yin 2009). The case study method is suited to answer "how" and "why" research questions and to provide an in-depth study of a phenomenon in its reallife context (Yin 2003, 2009). It is also suited to research questions requiring detailed understanding of organizational processes because of the rich data collected in context (Hartley 2004). Case studies allow an in-depth and contextually informed examination of specific organizations or events that explicitly address theory (Lee 1999). Case studies are widely recognized to be the preferred method when contemporary phenomena, such as proactive environmental strategy, are studied in their real-life contexts (Yin 2009). Finally, case studies are a systematic and organized way to 
produce information about a topic that will be valuable for practitioners (Cooper and Morgan 2008). Case studies can produce and communicate information about what companies do and how they do it (Collins 2001).

Our case study combines data stemming from different sources, such as interviews, internal and external documents completed by site visits to establish its construct validity and reliability (Eisenhardt 1989). The most important advantage of using multiple sources of evidence is the development of converging lines of inquiry, a process of triangulation and corroboration (Yin 2009).

\section{Case Selection}

The criteria used to select our case study related to four main issues: First, identifying an industry where environmental capabilities are essential to reduce the ecological footprint of both the company during the manufacturing process and the customers when using the product; second, identifying a company whose activity has an impact on the environment in terms of pollution and hazardous wastes and has consequently implemented a proactive environmental strategy; third, identifying a company whose proactive environmental strategy has gained sustainable competitive advantages through cost reduction, stakeholder integration, and continuous innovation in terms of environmental-friendly product; and fourth, identifying a company that has implemented MCS from an early stage of its proactive environmental strategy.

Xerox has implemented waste minimization, a pollution prevention program (Boiral 2006), and design for environment and product stewardship, initiatives that constitute a proactive environmental strategy (Berry and Rondinelli 1998). A sophisticated take-back and remanufacturing process allows equipment, parts, and components to be collected, reconditioned, tested to meet a "like new" condition, reassembled, and remarketed. This competitive product stewardship established Xerox as an early mover in new green product domains (Hart 1995; Lovins et al. 1999). Xerox's proactive environmental policy involves design and manufacturing functions working together with units responsible for interactions with customers (Hutchinson 1996; Russo and Fouts 1997). In this context, Xerox, as a business process and document management company, can be considered an environmentally proactive company and can therefore be classified as a representative case study from which lessons learned are assumed to be informative (Huberman and Miles, (1994) about its organizational processes and its proactive environmental strategy (Boiral 2006; Lovins et al. 1999).

Xerox has five manufacturing sites located in Webster (N.Y.), Dundalk (Ireland), Wilsonville (OR), Aubagne (France), and Venray (Netherlands) and sold nearly 2.5 billion units of equipment in 2016. Xerox's environmental responsibilities focus on climate protection, preserving biodiversity, preserving clean air and water, and preventing and managing waste. Xerox was the first in the market to introduce two-sided copying technology in 1969, the first to implement a recycled grade of cut paper in 1973, and the power-down mode in 1982. It has been involved in product remanufacturing since 1991, and in 1993 it became the first company as a Charter Partner in the Energy Star Program, a voluntary program launched in 1992 by the US Environmental Protection Agency with the objective of helping companies to reduce their energy consumption. Since 1991, its Environmental Health and Safety (EH\&S) policy has formed the foundation of Xerox's environmental leadership program. Xerox was the first in the market to introduce emulsion aggregation (EA) toner technology in 2002 and introduced the industry's first sustainability calculator in 2008. The company's manufacturing facilities have been certified ISO 14001 since 1997, and some have gone on to achieve certification to the recently issued ISO 50001 (energy management) standard. Finally, in 2007, Xerox opened the EA Toner plant, which was engineered to save energy thanks to thousands of sensors that track information about temperature, humidity, airflow, and other variables. More recently (2009), Xerox was the first to launch the solid ink technology in its ColorQube printers, which allow a smaller carbon footprint. However, this program was halted in 2016 due to an inadequate level of sales.

\section{Data Collection}

We obtained different types of data from the fieldwork: documentary (internal and external documents) and discursive (face-to-face interviews). Discursive data were obtained through face-to-face interviews conducted in June 2014 on Xerox's campus in Webster (N.Y.) with the Vice-President of Environment, Health, Safety and Sustainability, and nine EH\&S team members. All the interviews were audiorecorded and fully transcribed. They resulted in a corpus of 128,676 words (see Appendix 4). As interviews are essential sources of case study information (Yin 2009), focused interviews remained open-ended and conversational, but followed a set of questions derived from the case study protocol (Merton et al. 1990) (Appendix 1). The documents collected were for both internal and external uses and were provided by the EH\&S team, the partners to whom Xerox is committed, or through the Web site.

Triangulation of data, that is, varying the sources of the data collected, is an important criterion of internal validity (Bamford 2008). To satisfy this, the interviews were complemented by documentary data and some additional information obtained through site visits. Formal documentary data included the Energy Challenge (EC) 2012 and 2020 
program, through which Xerox made a public commitment to reduce its greenhouse gas emissions (GHG), initially from a 2002 baseline and later from a 2012 baseline; the Global Citizenship Report; the Environment Health and Safety Report; Environmental Metric Report; and EC 2012 Reporting Standards Presentation (see Appendix 3). These documents represent Xerox's overall environmental strategy during a 10-year period, from 1994 to 2014. This in-depth document analysis allowed us to put Xerox's environmental strategy, as well as the statements of people interviewed, into context. For case studies, the most important use of documents is to corroborate and argue evidence from other sources that provide specific details on a topic and allow inferences to be drawn from them (Yin 2009).

In recent years, companies have often turned to the Internet as their preferred method of communication in the interests of transparency and public accessibility, rather than to more traditional mass media channels. We have therefore included the content of Xerox's environmental Web site (Jose and Lee 2007; Maignan and Ralston 2002; Snider et al. 2003).

Finally, the data were enriched by site visits, resulting in the field notes used in the analysis. We made two visits, in June 2014, one to the Webster EA toner plant with the Toner Development Manager and the other to the customer innovation center. These visits enabled us to collect further evidence and additional information about the topic under study (Yin 2009).

\section{Data Analysis}

Data analysis was conducted by grouping and comparing several sources of information: interview transcripts, EH\&S documents, all the documentation collected, environmental performance data, and notes from the site visits. The categorization process makes possible to delve deeper into the interpretation of the data collected. This process is based on the grouping, codification, and comparison of information based on similar concepts or themes emerging from the data collection (Glaser and Strauss 1967). The qualitative software QSR NVivo was used to facilitate this inductive categorization process (Jiang and Bansal 2003; Welsh 2002). NVivo facilitates data management, coding, text retrieval, and theory testing and has become a widely used tool for qualitative research (Crowley et al. 2002). If, logically, parts of the preliminary categories were, a priori, derived from the literature review and the themes of the interview grid (Miles and Huberman 1994; Yin 2009), others emerged later during the categorization process (Appendix 2). These categories were then refined, modified, and subdivided throughout the qualitative analysis process. We then began searching for relationships among our categories in order to group them into second-order themes with a theoretical orientation toward understanding the role of MCS as a system to adequately convert proactive environmental strategy into actions. However, our conceptual framework emerged inductively from the categorization process (Yin 2009). From the second-order categorization, we consolidated our 46 first-order categories to five emerging themes in an abductive loop (O'Reilly et al. 2012): NGO partnerships; mandatory requirement of stringent regulations; internal and external reporting; environmental innovations, and sharing of best practices.

\section{Findings}

\section{A Proactive Environmental Strategy Relying on Environmental Capabilities}

Our findings highlight that Xerox has developed several environmental capabilities such as (1) stakeholder integration through its NGO partnerships and its willingness to anticipate environmental regulations; (2) stakeholder integration and shared vision through extensive internal and external reporting; (3) organizational learning through sharing best practices; (4) continuous innovation through extensive R\&D activities.

\section{NGO Partnerships}

In 2003, Xerox made a public commitment to reduce GHG emissions by joining the US Environmental Protection Agency (EPA) Climate Leaders Program and launching an internal program known as Energy Challenge 2012 (EC 2012). This program was renewed in 2012 and named "Energy Goal 2020, targets to reduce energy consumption by 20 percent by 2020 (from a 2012 baseline)" (Xerox Global Citizenship Report 2014). As nearly all of Xerox's GHG emissions are linked to the use of energy, this program is composed of different energy efficiency projects. "The EC 2012 is a corporate-wide initiative launched by the CEO; it relies on the active involvement of many departments/units within the company, such as manufacturing, corporate real estate, and technical services" (Environmental Sustainability Manager). Constant information about the EC2012 and the Energy Goal 2020 are disclosed through every kind of documents such as annual report, Web site, Global Citizen Report confirming information collected through interviews. One of the key elements of the EC 2012 and the Energy Goal 2020 management process is regular reviews with the program's steering committee and operational managers. These environmental commitments and NGO partnerships can be considered as a mean to integrate the stakeholders' expectations in the core business of the group. 
Yet, we must highlight that ethical values are extensively detailed in the Xerox Global Citizenship annual reports, illustrated by different practices and initiatives, while none of the interviewees mentioned that protecting the environment was just the "right thing to do from an ethical perspective." Indeed, all pollution prevention practices are connected with business performance and not with business ethics: "If you identify a good project that has a good financial payback, it's easy to sell the project on both sides: financial and environmental. Reducing the energy consumption allows us to save costs. You get both. We focus on the cost savings because it's business" (Environmental Program Manager in charge of energy reporting). Furthermore, more recently, Xerox has become a member of the New York Environmental Leaders Program, which provides recognition and incentives to businesses and organizations that are committed to sustainable practices and conserving natural resources. "It's good because even if we don't get an award if companies want to do business with us, they will look for things like that; it's more public relation. Over the years, it's becoming more and more important" (Environmental Sustainability Program Manager). Hence, the ethical implication of the stakeholder integration capability remains unclear. Indeed, managers may broadly engage NGO partnerships with the intent of enhancing the image and the reputation of the company rather than promoting the urgent need of addressing the climate change issue.

\section{Mandatory Requirement of Stringent Regulations}

Regulations significantly influence the company's environmental strategy, the first goal of which is to comply with all of them. "Our safety and supplier processes enable us to meet global regulations governing chemical use. Since 2007, Xerox's newly launched products have been designed to meet the European Union's Restriction of Hazardous Substances (RoHS) requirements in all markets" (Xerox Global Citizenship Report 2013). These regulations mentioned in different sources of information such as annual reports, internal documents and extensively detailed through interviews are increasingly stringent and ask for complete and detailed information about the environmental impact of the company. "I have noticed, over the last couple of years, that we have to provide more information through more specific dashboards. The EH\&S team has put in place a lot of more standardized systems for tracking the environmental data" (Environmental Project Manager of the EA Toner Plant, Webster). We can see that anticipation of future regulation is a means for Xerox to be environmentally proactive and to develop effective, cost-efficient compliance strategies that will minimize the risk of non-compliance. "Xerox needs to foresee the regulation requirements five or ten years ahead of time and adapts its strategy to these anticipated changes.
Investing in the appropriate 'green' facilities and modifying manufacturing processes or product components can anticipate the cost of compliance with future regulations" (Environmental Program Manager in charge of energy reporting). This anticipation of the environmental regulations is a key element of the stakeholder integration capability as the company seeks to maintain both its "licence to operate" and its competitive advantage.

\section{Internal and External Reporting}

The mandatory or voluntary reporting is extensively detailed in the Xerox Citizenship CSR reports, the annual reports, the Web site and described during the interviews as well. "We report yearly on our progress, including changes to our business and emerging issues. This report was prepared using the Global Reporting Initiative (GRI) G4 Sustainability Reporting Guidelines and contains Standard Disclosures" (Xerox Global Citizenship Report 2013). This company discloses environmental data to external stakeholders to comply with increasingly stringent environmental regulations or institutional frameworks. Furthermore, the internal reporting of environmental data is extensive and necessary, as it enables facility and plant managers to make comparisons between the results and targets of the whole environmental strategy. Hence, this internal and external reporting can be seen as a mean to develop both stakeholder integration and shared vision capabilities.

However, we must highlight that these CSR reports are quite similar from year-to-year, presenting the information mainly in a positive way. Moreover, we note that, even if environmental performance is disclosed over a five-year period, preset targets are disclosed for major topics only.

\section{Environmental Innovation}

Life cycle analysis is a way to address environmental opportunities as it prioritizes areas for future technology development. "The company's aim is to design product, packaging and supplies that make efficient use of resources, to minimize waste and re-use material where feasible, and recycle what cannot be reused" (Environmental Project Manager of the EA Toner Plant). Beginning in the early 1990s, Xerox pioneered the practice of converting end-oflife electronic equipment into products and parts that contain reused components: "Globally, the combined return program (equipment re-manufacture in conjunction with the re-use and recycling of parts and consumables) prevented nearly 46,000 metric tons of waste in 2010" (Xerox Global Citizenship Report 2011). The monthly EH\&S review meeting considers any project, whether for a new product launch or a new manufacturing process: "From an energy perspective, facility managers and operational managers present 
different projects detailing the energy savings over a period of three or five years. The EH\&S team works regularly with engineers and operating or facility managers to suggest improvements in energy use" (Environmental Program Manager in charge of energy reporting). Hence, we can see that a strong innovation capability is more likely to respond to technological uncertainty with a proactive clean technology strategy than one that lacks such capability. Yet the return on investment of environmental innovation determines the continuity of the program. For example, production of ColorQube printers, which rely on solid ink technology that offers customers a lower carbon footprint, was stopped in 2016 only 7 years after its launch because sales did not reach preset targets: "Every customer is keen to buy an ecological product, but no one is ready to pay an extra price for it" (Vice President of Environment Health, Safety and Sustainability).

\section{Sharing of Best Practices}

A collaborative effort between the EH\&S team members on the one hand, and facility and operations managers on the other, takes place through monthly meetings about the key pollution indicators for improving environmental performance and cost savings. "The EH\&S team stretches goals in order to drive environmental innovations and challenge operational managers to be more energy-efficient" (Energy Manager for the EA Toner plant, Webster). Managerial cognition relies on environmental performance measurements, as "what gets measured gets managed. Setting challenging but achievable goals is a means of rallying the management team around the energy reduction program and enabling environmental performance improvement" (Vice President of Environment Health, Safety and Sustainability).

In many respects, Xerox has developed a proactive environmental strategy that conforms to environmental regulations and relies on extensive internal and external reporting, NGO partnerships, sharing of best practices and, finally, environmental innovation in pollution prevention, product stewardship and clean technology. These capabilities, presented in Table 1, can be summarized around the shared vision, stakeholder integration, organizational learning and continuous innovation-specific environmental capabilities.

\section{Management Control Systems as a Means of Enhancing Environmental Capabilities}

Belief systems, such as citizenship reports, Web site, EPA feedback and internal documents shared by a large number of employees, as well as external stakeholders, are used to present the mission statement as the shared vision of the company. "Reducing our Company-wide Carbon Footprint: While our ultimate goal is to be climate-neutral, our first priority is to reduce our total greenhouse gas (GHG) emissions by lowering the energy intensity of our operations" (Xerox Citizenship annual Reports). Hence, shared vision is enhanced through belief systems that put forward the strategic environmental commitment of the company. "We have conducted a comprehensive review of the environmental impact of our company and have identified four strategic

Table 1 Xerox's proactive environmental strategy and environmental capabilities

\begin{tabular}{|c|c|c|c|}
\hline Strategic capability & Environmental driving force & Key resource & Competitive advantage \\
\hline Stakeholder integration & $\begin{array}{l}\text { Compliance with regulations } \\
\text { Compliance with customer requirements } \\
\text { Hazardous waste treatments } \\
\text { EC } 2012 \\
\text { N.Y. Environmental Leaders }\end{array}$ & $\begin{array}{l}\text { EH\&S reporting } \\
\text { ISO } 14001 \text { reporting } \\
\text { Environmental programs } \\
\text { Environmental partnerships } \\
\text { Environmental agencies relationships } \\
\text { ISO } 14001\end{array}$ & $\begin{array}{l}\text { Lower the regulatory cost } \\
\text { Brand reputation } \\
\text { Better relationships } \\
\text { Influence regulation }\end{array}$ \\
\hline Shared vision & $\begin{array}{l}\text { Reduction in emissions, effluents, waste } \\
\text { Climate-neutral } \\
\text { EC } 2012 \\
\text { Remanufacturing, recycling, reusing }\end{array}$ & $\begin{array}{l}\text { Environmental innovation } \\
\text { Targets challenging but achievable } \\
\text { Collaborative way of working } \\
\text { ISO } 14001 \\
\text { CSR annual reports }\end{array}$ & $\begin{array}{l}\text { First mover } \\
\text { Employee commitment } \\
\text { Cost saving }\end{array}$ \\
\hline Organizational learning & $\begin{array}{l}\text { Frequent meetings } \\
\text { Cross-organizational team } \\
\text { Process and routines }\end{array}$ & $\begin{array}{l}\text { Environmental innovation } \\
\text { Patents } \\
\text { Best practice sharing }\end{array}$ & $\begin{array}{l}\text { First mover } \\
\text { Influence regulation } \\
\text { Green product } \\
\text { Cost saving }\end{array}$ \\
\hline Continuous innovation & $\begin{array}{l}\text { EA Toner plant } \\
\text { EA Toner } \\
\text { Sustainability Calculator } \\
\text { Eco-conception } \\
\text { ColorQube program } \\
\text { Solid ink printers }\end{array}$ & $\begin{array}{l}\text { Environmental innovation } \\
\text { Patents } \\
\text { Reusing, recycling, remanufacturing processes }\end{array}$ & $\begin{array}{l}\text { First mover } \\
\text { Lower manufacturing costs } \\
\text { Green product } \\
\text { Energy savings }\end{array}$ \\
\hline
\end{tabular}


commitment areas where we can make a significant positive impact: (1) Reducing Energy Use and Protecting the Climate, (2) Preserving the World's Forests and Biodiversity, (3) Preserving Clean Air and Water, (4) Preventing and Managing Waste" (Xerox Citizenship annual Reports). This shared vision is supported by several targets presented as strategic goals either in written documents or disclosed during the interviews: "zero persistent, bio-accumulative, toxic footprint," "water neutral," "zero hazardous or pollutants," "waste-free facilities or products," "zero waste to landfill for major facilities worldwide" (Xerox Global Citizenship reports).

In order to enhance the shared vision of the company, the facility and plant managers set environmental goals and objectives collaboratively with the EH\&S team during frequent work meetings. "Each year, they set their energy reduction goals in relation to the previous year's performance and the following year's forecast" (Environmental Sustainability Program Manager). Moreover, belief systems are used to enhance the commitment of every environmental manager leading them either to suggest a new environmental program or to improve some manufacturing process to reduce pollution or energy consumption. "Stretch goals are seen to drive innovation and challenge people but if they are not achievable, facility and plant managers won't waste their time trying to achieve them. Goals have to be achievable and stretch, too, in order to rally operational units around the success of the environmental strategy" (Vice-President of Environment Health, Safety and Sustainability). Those goals, detailed during the interviews by the EH\&S team, are extensively disclosed in many internal and external documents. Finally, some activities of this shared vision are implemented collaboratively with partners such as NGOs, the Nature Conservancy (to support a sustainable paper cycle), or the Environmental Protection Agency (EPA) (to support the Energy Challenge commitment). "In the U.S., Xerox recently partnered with a large electronics recycler to ensure that our customers have a means to have their old imaging devices processed in a responsible manner" (Xerox Global Citizenship Report 2014).

Boundary systems are used to present the shared vision of the company to all the employees through specific documents, such as those related to the EPA partnership, the ISO 14001 reporting or the EC 2012 and Energy Goal 2020 program that define the organization and the mission of the EH\&S team. However, boundary systems are also used to integrate stakeholders' expectations into the different phases of the environmental strategy implementation through frequent meetings with NGOs. "The EH\&S team have all of the responsibility for communicating with outside agencies, and keep their fingers on what's going on with our stakeholders, with our customers, with regulations. They come up with ideas of what we should do and our role is both to implement what we have to do, and to feed back 'realworld considerations' on what we can really do. Can we do that? Can we not? Is it too aggressive? Is it not aggressive enough?" (Environmental Project Manager of the EA Toner Plant). Consequently, these practices show how boundary systems are used to improve the stakeholder integration and the shared vision capabilities throughout the company.

DCS, such as standardized environmental templates, are used to disclose GHG emissions, energy and water consumption, hazardous waste discharge, or reused, recycled, or remanufactured equipment, either internally to the EH\&S team or externally to all the stakeholders to whom the company is committed. "The release of materials used in our worldwide operations is evaluated annually and reported to government agencies under national toxic chemical release reporting regulations, such as the U.S. Toxics Release Inventory, the Canadian National Pollutant Release Inventory, and the European Pollutant Release and Transfer Register" (Xerox Global Citizenship annual reports). Thus, DCS, through these shared environmental templates, can be considered as a tool enhancing the stakeholder integration capability. Moreover, the DCS provide feedback to EH\&S top managers through the monitoring of environmental performance on an exceptional basis and rewards the achievement of preset goals: "Very specific indicators are tracking energy consumption over the Webster campus. These indicators can very closely monitor changes that happened monthly and make projections and determinations on what happening on the Webster campus and what is possible for the future" (Environmental Engineer focusing on water). DCS are used by the EH\&S team to evaluate the qualitative improvement of their environmental management practice and to challenge managers to improve it: "In 2010 an environmental dashboard was implemented to assess how facility or plant units were progressing toward the corporate goals in their annual targets" (Environmental Sustainability Manager). Hence, we can see that DCS can be used to trigger the organizational learning capability through the monitoring of environmental performance. Top managers in the EH\&S team view this feedback as a means of improving environmental performance by focusing on the difficulties encountered and the way they are faced: "The environmental performance measurement provides guidance to facility or plant managers to achieve their goals by focusing on targets and by correcting deviations from the pre-set standards. Frequent reviews of these key indicators improve the coordination of the implementation of the environmental strategy over time" (Vice-President of Environment Health, Safety and Sustainability). Consequently, DCS is used to enhance continuous innovation capabilities that can lead to competitive advantage for the company.

ICS allows top environmental managers to get involved in the managerial decisions of facility or plant managers 
through frequent face-to-face meetings focusing on strategic uncertainties, such as new environmental regulations to be met. The involvement of EH\&S top managers occurs during regular meetings with the Environmental Manager Operations (EMO) or Energy Manager Representative (EMR) for each facility or plant. "These monthly environmental network meetings monitor the results toward environmental goals, allow the presentation of best practices implemented by different EMOs or EMRs, and facilitate learning from other managers or engineers about how to deal with a particular environmental subject. This learning process is enhanced by the EH\&S team, which organizes and participates in the meetings on different environmental topics: they ask managers for further explanations of their targets or results, and reshape the corporate goal when necessary" (Environmental Sustainability Program Manager). The collaborative way of working between EH\&S team members and facility and operations managers facilitates information sharing and coordination. Thus, ICS, through frequent meetings, enhance organizational learning capability. "Things go both ways with the EH\&S team: we bring them the project that we have identified and they look at the project, and they make sure that this project counts for the GHG reduction associated with this project and rolled up for the corporate environmental goal. The EH\&S team brings us kind of knowledge, like during the North American Council, they can bring ideas coming from other sites, and bring knowledge on different practices on water savings, for example, we are not good at that" (Energy Manager for the EA Toner plant, Webster). The same goes for the clean technology projects with teams that work under the leadership of the environmental engineer facilitating sharing best practices and the learning process. In this context, it is worth observing that the financial aspect of any project to some extent determines its implementation. Return on investment and energy saved are extensively studied as key performance indicators of new technologies and projects. Consequently, our findings highlight how ICS can enhance continuous innovation capability through frequent regular meetings that facilitate information sharing and coordination.

Table 2 presents the characteristics of the levers of control of MCS of Xerox's environmental strategy. It details key design variables and the purpose of each of the levers of control, giving examples.

Our results show that the four levers of control are used interactively to enhance environmental capabilities. Indeed, belief and boundary systems set the shared vision and objectives of environmental performance on the one hand, and the rules and limits that the company has to comply with on the other. The DCS monitors environmental performance through goal-setting, regular reporting, and deviation analyses on a regular basis to make sure that environmental performance complies with the regulations or voluntary commitment. Moreover, DCS are used to provide the EH\&S team and operational managers with detailed information so that they can improve environmental performance. ICS are used to share best practices between environmental managers. The frequent involvement of the EH\&S team, which focuses on strategic environmental uncertainties, shows that ICS can also stimulate new initiatives.

\section{Discussion}

The purpose of this study is to describe how a company can use the four levers of control to enhance its environmental capabilities, which in turn, can contribute to competitive advantage. Based on our findings, we propose a conceptual framework of the four levers of control that companies can use to enhance stakeholder integration, shared vision, organizational learning, and continuous innovation

Table 2 Characteristics of the four levers of control of MCS of Xerox's environmental strategy

\begin{tabular}{|c|c|c|c|c|}
\hline Nature of systems & Belief systems & Boundary systems & Diagnostic control systems & Interactive control systems \\
\hline Key design variables & Shared vision & Compliance & Monitoring & Anticipation \\
\hline Purpose & $\begin{array}{l}\text { Provide environmental strat- } \\
\text { egy direction } \\
\text { Provide guidance for environ- } \\
\text { mental R\&D }\end{array}$ & $\begin{array}{l}\text { Conformity with the EC } \\
2012 \text { program } \\
\text { Conformity with regula- } \\
\text { tions } \\
\text { Avoid regulatory costs }\end{array}$ & $\begin{array}{l}\text { Provide information to facil- } \\
\text { ity or plant managers }\end{array}$ & $\begin{array}{l}\text { Focus EH\&S teams' attention } \\
\text { on environmental strategic } \\
\text { uncertainties }\end{array}$ \\
\hline Examples & $\begin{array}{l}\text { "We believe that Xerox, as } \\
\text { a global business, must do } \\
\text { its part to reduce the risk of } \\
\text { climate change" }\end{array}$ & $\begin{array}{l}\text { EC } 2012 \text { program } \\
\text { ISO } 14001 \text { certification } \\
\text { Environmental regulation } \\
\text { Supplier } \\
\text { requirements }\end{array}$ & $\begin{array}{l}\text { Challenging but achievable } \\
\text { goals } \\
\text { Yearly and monthly plan } \\
\text { Monthly review of environ- } \\
\text { mental indicators } \\
\text { Year-on-year comparison } \\
\text { Results of goal-achievement } \\
\text { review }\end{array}$ & $\begin{array}{l}\text { Influence environmental } \\
\text { regulations } \\
\text { Sharing best practices } \\
\text { Face-to-face meetings } \\
\text { New challenging environmen- } \\
\text { tal program }\end{array}$ \\
\hline
\end{tabular}


capabilities with the objective of gaining competitive advantages (Fig. 1).

\section{Stakeholder Integration Capability is Enhanced by the Joint use of Belief and Boundary Systems and DCS}

The stakeholder integration capability within the organization implies that the company pays attention to its stakeholders' concerns, such as ethical, environmental, and social issue when setting its objectives. The joint use of belief and boundary systems and to a lesser extent DCS can adequately help integrate stakeholders' different and increasing expectations. Indeed, the joint use of belief and boundary systems may help company learning about product life cycle and designing environmental-friendly products and services from suppliers and customers' expectations. Moreover, belief systems may enhance employee stakeholder integration that will trigger a pervasive business ethics where all individuals are involved in greening the company. Hence, the joint use of boundary systems and DCS can set environmental indicators, monitor environmental performance, and correct deviations from preset standards of performance, meeting stakeholders' expectations. Moreover, boundary systems can be used to identify and manage risks, such as new environmental regulations, providing a competitive advantage by reducing regulatory costs. Stakeholder integration is not enhanced by ICS since this system is mainly used from an internal rather than an external perspective. Indeed, ICS facilitate organizational learning and environmental innovation capabilities once stakeholders' expectations are determined and taken into account.

\section{Shared Vision Capability is Enhanced by the Joint Use of Belief and Boundary Systems}

Belief systems shared by all employees can be activated through mission statements that inspire the search for new opportunities in line with environmental values. Indeed, as boundary and belief systems are used to ascertain that employees behave according to pre-established rules, these levers of control provide limits and force organizations to convert intended strategy into action. A joint use of these two levers of control can foster shared vision capability supporting pollution prevention activities that can lead to competitive advantage in the form of cost reduction. Belief and boundary systems can encourage employees to participate in environmental decision making, facilitate their involvement in environmental activities, and finally be rewarded for environmental good practices at work. It must be highlighted that DCS are not used to enhance shared vision capability since there is no need to monitor it or to correct its deviation. ICS are not used either to enhance shared vision capability since it enhances organizational learning or continuous innovation capabilities once the shared vision has been set by the company. Finally, interpretation of environmental strategy may diverge across organizational levels, due to diversity of interests among managers and employees. Hence, the joint use of belief and boundary systems may enhance a shared vision capability that provides goal clarity by mitigating
Fig. 1 Conceptual framework of management control levers enhancing environmental capabilities

\section{Levers of control}

\begin{tabular}{|l}
\hline Belief systems \\
Boundary systems \\
DCS
\end{tabular}

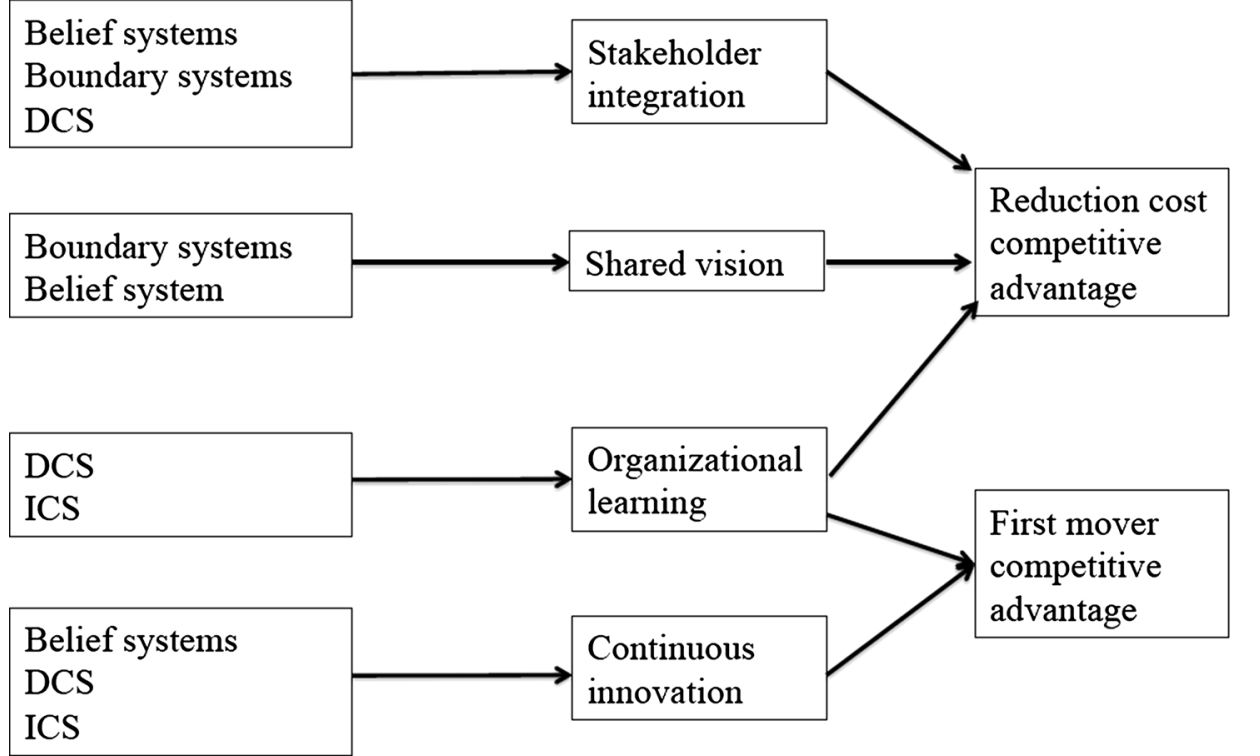

\section{Environmental capabilities \\ Competitive advantage}

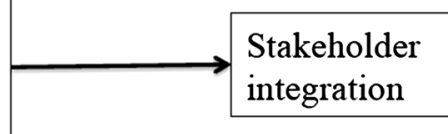


ambiguities and conflicting interests and coordinating the focus of departments and teams.

\section{Organizational Learning Capability is Enhanced by the Use of ICS and to a Lesser Extent by the Use of DCS}

Using DCS, environmental managers can set goals that are challenging yet achievable, so that a company always seeks to improve its environmental performance. Indeed, an adequate environmental measurement system improves the deviation analysis of goal-related results and year-onyear progression. Furthermore, ICS can be used to enhance the sharing of best practices through frequent meetings between top managers and operational environmental managers. Indeed, interaction and coordination between business units are essential to enhance organizational learning. One of the objectives of ICS is to enhance organizational learning through the extensive communication of strategic goals. ICS can therefore be used to stimulate the disclosure and sharing of environmental data between environmental and facility managers through frequent working meetings. Finally, the joint use of DCS and ICS, stimulating organizational tensions such as dealing simultaneously with goal achievement and new initiatives emerging from threats and opportunities, can also help develop organizational learning capabilities that can lead to a first-mover advantage. In an environmental strategy context, the company can encourage a collaborative way of working, such as sharing best practices.

Belief and boundary systems are not used to enhance organizational learning since they are used to set the shared vision of the company and the integration of stakeholders' expectations around which the company maps its environmental strategy.

\section{Continuous Innovation Capability is Enhanced Mainly by the Use of ICS and Belief Systems and to a Lesser Extent DCS}

ICS can be used to focus organizational attention on strategic uncertainties to prompt the emergence of new initiatives; in consequence, frequent face-to-face meetings with operational units foster awareness of difficulties in implementing an environmental strategy. Using belief systems and ICS to encourage innovative behaviors can stimulate opportunityseeking and innovation, resulting in the definition of new strategy. The joint use of these two levers of control can help develop clean technology capabilities that can lead to a first-mover advantage on the green product market. Indeed, the outcomes of continuous innovation capability may be renewal in manufacturing process or in products. As other firms may easily imitate first movers' successful innovations, the capability of continuously generating such innovations contributes to a firm maintaining its lead in its environmental practices. In that context, the joint use of belief systems, DCS, and ICS may enhance this capability by stimulating new initiative in the specific environmental credo of the company while measuring the costs and economic benefits of these innovations.

Boundary systems are not used to enhance continuous innovation capability since environmental innovations are proposed, studied, and implemented by the environmental team while respecting the most stringent environmental regulation. Indeed, continuous innovation capability allows the company to improve its environmental performance in terms of its preset goals without getting around environmental regulations.

This conceptual framework underlines the key role of the joint use of the four levers of control. Indeed, ICS can foster environmental capabilities that rely on co-working and sharing best practices, such as organizational learning or continuous innovation, while belief and boundary systems are used more to integrate stakeholders' expectations and rally round all the company's employees. DCS is clearly used for monitoring purposes as a precondition for ICS to play its full role.

\section{Theoretical Contributions}

From a management control perspective, this study contributes to highlight some new associations of levers of control. Generally, ICS and belief systems are used jointly to empower organizational actors, while DCS and boundary systems are used jointly to elaborate on and interpret findings (Gond et al. 2012; Henri 2006; Simons 1995). Our findings show that a company can use boundary and beliefs systems jointly to enhance the shared vision capability and can use DCS and ICS jointly to enhance organizational learning capability. Moreover, our study shows that, contrary to Simons $(1995,2000)$ and Henri (2006), DCS can contribute to the development and the maintenance of the organizational learning and continuous innovation capabilities. Finally, our findings show that every lever of control is not required with the same intensity for the development of environmental capabilities. Indeed, stakeholder integration and continuous innovation capabilities are implemented with three levers of control while only two levers of control develop shared vision and organizational learning capabilities. Hence, this study challenges the common view that management control systems are equally needed to support strategy in all contexts.

From the environmental capability perspective, our findings highlight that stakeholder integration with continuous innovation may help identify opportunities for reducing pollution, whereas shared vision and organizational learning may enhance improvements in environmental-friendly 
products. In that context, the four levers of control enhance the cross-functional management capability which in turn trigger the corporate performance, improve the reputation of the company, and facilitate strategic alignment with future changes in the general business environment.

Finally, this study contributes to the business ethics debate on the reasons why managers develop a stakeholder integration capability. While the stakeholder theory argues that the integration of stakeholders reflects an ethical consideration, our study highlights the "dark side" of the development of this capability in which managers may want to enhance their reputation and follow their own financial goals. In some way, managers can develop the stakeholder integration capability in an opportunistic way.

\section{Conclusion}

This study aims to examine how a company can use Simons' (1995) four levers of control to enhance environmental capabilities, which in turn, can contribute to a competitive advantage. From our findings, we propose a conceptual framework of management control levers that shows how companies can foster (1) stakeholder integration capability through the joint use of belief systems, boundary systems, and DCS; (2) shared vision capability through the joint use of belief and boundary systems; (3) organizational learning capability through the joint use of DCS and ICS; and (4) continuous innovation capability through the use of ICS, belief systems, and to a lesser extent DCS.

This model enhances our knowledge of both the use, rather than the existence, of various tools and systems when making environment-related decisions, and the identification of the genesis of environmental capabilities, thus answering several calls in the literature (Aragon-Correa and Sharma 2003; Arjaliès and Mundy 2013; Journeault 2016; Molloy et al. 2011). Moreover, this framework may help managers figure out what combination of levers of control they should use to enhance some specific environmental capabilities.

Nevertheless, there are limitations to this research that must be acknowledged. The single case study method, the goal of which is to describe complex phenomena rather than measure their frequency and correlations to extrapolate to the general population (Eisenhardt 1989), limits the possibility of generalizing these results to other organizations. Consequently, these results are specific and contingent, even if it is reasonable to think that the observed phenomena apply, to a certain extent, to other certified organizations. Other limitations relate to Xerox's manufacturing activity, since its GHG emissions are mainly a result of its energy consumption. Pollution control and prevention are focused primarily on a few specific pollution sources rather than several different ones, which could lead to more complex pollution control and prevention systems. Furthermore, these reduced pollution sources allow a proactive environmental program that is focused predominantly on energy reduction that facilitates goalsetting, monitoring, and management. This study calls for future research that could examine how companies from different industries can use the four levers of control to enhance their environmental capabilities. Indeed, the type of industry, the governmental regulations that affect it and the manufacturing process seem to be a determinant factor in the design of the environmental strategy and as a consequence in the development of the environmental capabilities. Furthermore, it could be interesting to understand how the consequences of the climate change in terms of rising of temperature and resource depletion may influence the development of some specific environmental capabilities for those companies that have to deal with those effects.

\section{Compliance with Ethical Standards}

Conflict of Interest The author Elisabeth Albertini declares that she has no conflict of interest.

\section{Appendix 1: Main Guidelines for the Interviews with EH\&S Team Members}

1. EH\&S team

Description of the job position in the EH\&S Team

Description of Xerox's environmental strategy and its evolution

i.e., priorities, pollution control, pollution prevention, environmental innovation: product, manufacturing process

Role of the EH\&S team in the implementation of environmental strategy

i.e., set or provide guidelines, managing environmental strategy, challenging environmental performance, reshaping or replacing environmental strategy, monitoring results, reporting data, employee training

Certification ISO 14001

Energy Challenge 2012 program and role of the EH\&S team in that program

i.e., corporate communication about the EC2012 program outside and inside the company.

Xerox's commitment to the EPA Climate Leaders Program

Description of the Lean Six Sigma process developed for implementing the Energy Challenge 2012 


\section{Target and goals}

First target: reduction by $10 \%$ greenhouse gas emission between 2002 and 2012

i.e., setting goals, previous analyses, involvement of the manufacturing team or facilities management team

Evolution of the target of the program, setting a new program

Explanation of the success of the first EC2012 program

3. Data gathering and analysis

Procedure, frequency, measurement tool, monitoring system

Who is concerned? What kind of reporting?

4. Diagnostic control system

i.e., description of the goal and objective systems, indicators used to monitor and manage environmental performance, reporting, revision of the goal or objective.

i.e., description of the automatic management tool (the Johnson Control Energy and Emissions Management Tool)

i.e., audit and certification of the data disclosed

5. Interactive control system between EH\&S team and other managers

i.e., meeting between EH\&S team and other managers, frequency, objectives, support, face-to-face or team meeting, involvement of the top managers in environmental strategy, description of the "action plans," description of the strategic uncertainties of Xerox's corporate environmental strategy

\section{Appendix 2: NVivo Coding Themes}

\section{Hart (1995): Natural-resource-based theory}

Pollution control and prevention: Pollution control: storage of emisminimize emissions, effluent, and waste

Product stewardship
Simons (1995): four levers of control

Belief systems (core values) Mission statements, vision statements, credo, statements of purpose, target market

Boundary systems (types of behavior no longer allowed, risks to be avoided)

Clear rules, limits, code of business conduct, operational guidelines, strategic planning systems, assets acquisition regulations, capital budgeting systems

Interactive control systems (stra- Face-to-face debate, meeting with tegic uncertainties) operating managers, focus of attention, involvement of top managers, assumptions and action plans of subordinates, concentration on strategic uncertainties, continually challenging, action plans, management tool, reshape or replace the strategy, strategic uncertainties

Diagnostic control systems (criti- Profit plans, budgets-investcal performance variables) ments, goals, and objectives systems, monitoring and coordination systems, indicators, review of critical performance indicators, correcting deviation, measurement systems, feedback, achievement, audit

\section{Appendix 3: Inventory of Documentary Data} sions or effluent, treatment of emissions or effluent, pollution control equipment or device, preserving (protecting) clean air, water, biodiversity

Strategy prevention: reduction in emissions or effluent (greenhouse gas emissions), prevention of emissions or effluent, housekeeping, material substitution, manufacturing process innovation, reduction in energy consumption or water consumption, employee involvement, continuous improvement of emission reduction, cost advantage for customers, cost saving for the company

Life cycle analysis of the product, supplies return, reuse, recycling program, eco-design of the product, environmental innovation (product), competitive advantage (product), suppliers' requirements, value chain leverage, long-term approach, green product, leader position

\begin{tabular}{|c|c|c|c|c|}
\hline $\begin{array}{l}\text { Type of } \\
\text { document }\end{array}$ & Description & Authors & Date & Diffusion \\
\hline Pdf & $\begin{array}{l}\text { Energy } \\
\text { Managers' } \\
\text { quarterly } \\
\text { newsletter }\end{array}$ & $\begin{array}{l}\text { Environ- } \\
\text { mental } \\
\text { Sustain- } \\
\text { ability } \\
\text { Manager }\end{array}$ & $\begin{array}{r}\text { March } \\
2008\end{array}$ & Internal \\
\hline Pdf & $\begin{array}{l}\text { Energy } \\
\text { challenge } \\
2012 \\
\text { reporting }\end{array}$ & $\begin{array}{l}\text { Health and } \\
\text { Safety } \\
\text { and Sus- } \\
\text { tainability } \\
\text { Depart- } \\
\text { ment }\end{array}$ & $\begin{array}{l}2002 \text { and } \\
2006\end{array}$ & $\begin{array}{l}\text { Internal/ } \\
\text { external }\end{array}$ \\
\hline Pdf & $\begin{array}{l}\text { Global Citi- } \\
\text { zenship } \\
\text { Report }\end{array}$ & $\begin{array}{l}\text { Health and } \\
\text { Safety } \\
\text { and Sus- } \\
\text { tainability } \\
\text { Depart- } \\
\text { ment }\end{array}$ & $\begin{array}{c}2006 \text { to } \\
2016\end{array}$ & External \\
\hline Pdf & $\begin{array}{l}\text { Environ- } \\
\text { mental } \\
\text { Health } \\
\text { and Safety } \\
\text { Report }\end{array}$ & $\begin{array}{l}\text { Health and } \\
\text { Safety } \\
\text { and Sus- } \\
\text { tainability } \\
\text { Depart- } \\
\text { ment }\end{array}$ & $\begin{array}{c}2006 \text { to } \\
2015\end{array}$ & Internal \\
\hline
\end{tabular}




\begin{tabular}{|c|c|c|c|c|}
\hline $\begin{array}{l}\text { Type of } \\
\text { document }\end{array}$ & Description & Authors & Date & Diffusion \\
\hline Pdf & $\begin{array}{l}\text { Environ- } \\
\text { mental } \\
\text { Protection } \\
\text { Agency } \\
\text { partner- } \\
\text { ship }\end{array}$ & $\begin{array}{l}\text { Health and } \\
\text { Safety } \\
\text { and Sus- } \\
\text { tainability } \\
\text { Depart- } \\
\text { ment }\end{array}$ & $\begin{array}{c}2006 \text { to } \\
2010\end{array}$ & External \\
\hline Pdf & $\begin{array}{l}\text { Preserv- } \\
\text { ing Our } \\
\text { Planet } \\
\text { through } \\
\text { Sustain- } \\
\text { able Inno- } \\
\text { vation and } \\
\text { Develop- } \\
\text { ment }\end{array}$ & $\begin{array}{l}\text { Health and } \\
\text { Safety } \\
\text { and Sus- } \\
\text { tainability } \\
\text { Depart- } \\
\text { ment }\end{array}$ & 2011 & External \\
\hline Pdf & $\begin{array}{l}\text { White } \\
\text { Paper, } \\
\text { EPS Sus- } \\
\text { tainabil- } \\
\text { ity, Xerox } \\
\text { Enterprise } \\
\text { Print } \\
\text { Service }\end{array}$ & $\begin{array}{l}\text { Environ- } \\
\text { mental } \\
\text { Sustain- } \\
\text { ability } \\
\text { Manager }\end{array}$ & 2010 & Internal \\
\hline Pdf & $\begin{array}{l}\text { White } \\
\text { paper, } \\
\text { Smarter } \\
\text { Ways to } \\
\text { Green: } \\
\text { How to } \\
\text { Make } \\
\text { Sustain- } \\
\text { ability } \\
\text { Succeed } \\
\text { in Your } \\
\text { Business }\end{array}$ & $\begin{array}{l}\text { Vice } \\
\text { President } \\
\text { Environ- } \\
\text { ment, } \\
\text { Health } \\
\text { and } \\
\text { Safety }\end{array}$ & 2008 & External \\
\hline Pdf & $\begin{array}{l}\text { Xerox and } \\
\text { Paper: A } \\
\text { Sustain- } \\
\text { ability } \\
\text { Reference } \\
\text { Guide }\end{array}$ & $\begin{array}{l}\text { Senior Vice } \\
\text { President, } \\
\text { Xerox } \\
\text { Supplies } \\
\text { Business } \\
\text { Group }\end{array}$ & 2008 & $\begin{array}{c}\text { Internal and } \\
\text { external }\end{array}$ \\
\hline Pdf & $\begin{array}{l}\text { Xerox and } \\
\text { the Envi- } \\
\text { ronment: } \\
\text { Our Sus- } \\
\text { tainability } \\
\text { Commit- } \\
\text { ment- } \\
\text { Briefing } \\
\text { Paper for } \\
\text { Xerox } \\
\text { Custom- } \\
\text { ers }\end{array}$ & $\begin{array}{l}\text { Office and } \\
\text { Solution } \\
\text { Business } \\
\text { Group } \\
\text { (mar- } \\
\text { keting } \\
\text { product) }\end{array}$ & 2010 & $\begin{array}{c}\text { Internal and } \\
\text { external }\end{array}$ \\
\hline Pdf & $\begin{array}{l}\text { Green } \\
\text { Product } \\
\text { Speci- } \\
\text { fication } \\
\text { Develop- } \\
\text { ment }\end{array}$ & $\begin{array}{l}\text { Product } \\
\text { Manager }\end{array}$ & $\begin{array}{l}2008 \text { and } \\
2010\end{array}$ & Internal \\
\hline
\end{tabular}

\begin{tabular}{|c|c|c|c|c|}
\hline $\begin{array}{l}\text { Type of } \\
\text { document }\end{array}$ & Description & Authors & Date & Diffusion \\
\hline Pdf & $\begin{array}{l}\text { Xerox } \\
\text { guides } \\
\text { customers } \\
\text { to print } \\
\text { responsi- } \\
\text { bly: Help- } \\
\text { ing to } \\
\text { meet the } \\
\text { challenge } \\
\text { of sus- } \\
\text { tainable } \\
\text { printing }\end{array}$ & $\begin{array}{l}\text { Graphic } \\
\text { Commu- } \\
\text { nication } \\
\text { Business } \\
\text { Group } \\
\text { (market- } \\
\text { ing print- } \\
\text { ing) }\end{array}$ & 2010 & $\begin{array}{c}\text { Internal and } \\
\text { external }\end{array}$ \\
\hline PowerPoint & $\begin{array}{l}\text { Xerox Cor- } \\
\text { poration } \\
\text { Environ- } \\
\text { mental } \\
\text { Sustain- } \\
\text { ability }\end{array}$ & $\begin{array}{l}\text { Health and } \\
\text { Safety } \\
\text { and Sus- } \\
\text { tainability } \\
\text { Depart- } \\
\text { ment }\end{array}$ & $\begin{array}{l}2012 \text { and } \\
2014\end{array}$ & Internal \\
\hline PowerPoint & $\begin{array}{l}\text { Xerox } \\
\text { Enterprise } \\
\text { Print } \\
\text { Services: } \\
\text { Sustain- } \\
\text { ability } \\
\text { is smart } \\
\text { business }\end{array}$ & $\begin{array}{l}\text { Educa- } \\
\text { tion and } \\
\text { Learning } \\
\text { Depart- } \\
\text { ment }\end{array}$ & 2009 & Internal \\
\hline PowerPoint & $\begin{array}{c}\text { Xerox Case } \\
\text { Studies- } \\
\text { Good for } \\
\text { Business, } \\
\text { Good for } \\
\text { the Envi- } \\
\text { ronment }\end{array}$ & $\begin{array}{l}\text { Educa- } \\
\text { tion and } \\
\text { Learning } \\
\text { Depart- } \\
\text { ment }\end{array}$ & 2009 & Internal \\
\hline PowerPoint & $\begin{array}{l}\text { Xerox Inno- } \\
\text { vation, } \\
\text { Good for } \\
\text { Business, } \\
\text { Good for } \\
\text { the Envi- } \\
\text { ronment } \\
\text { Innovation } \\
\text { in paper } \\
\text { Innovation } \\
\text { in toner } \\
\text { Innovation } \\
\text { in multi- } \\
\text { function } \\
\text { devices }\end{array}$ & $\begin{array}{l}\text { Educa- } \\
\text { tion and } \\
\text { Learning } \\
\text { Depart- } \\
\text { ment }\end{array}$ & 2009 & Internal \\
\hline PowerPoint & $\begin{array}{l}\text { Environ- } \\
\text { mental } \\
\text { Sustaina- } \\
\text { bility: Our } \\
\text { Commit- } \\
\text { ment }\end{array}$ & $\begin{array}{l}\text { Health and } \\
\text { Safety } \\
\text { and Sus- } \\
\text { tainability } \\
\text { Depart- } \\
\text { ment }\end{array}$ & $\begin{array}{l}2010 \text { and } \\
2012\end{array}$ & $\begin{array}{c}\text { Internal and } \\
\text { external }\end{array}$ \\
\hline PowerPoint & $\begin{array}{l}\text { Sustain- } \\
\text { ability } \\
\text { Reporting }\end{array}$ & $\begin{array}{l}\text { Health and } \\
\text { Safety } \\
\text { and Sus- } \\
\text { tainability } \\
\text { Depart- } \\
\text { ment }\end{array}$ & 2010 & Internal \\
\hline
\end{tabular}




\begin{tabular}{|c|c|c|c|c|}
\hline $\begin{array}{l}\text { Type of } \\
\text { document }\end{array}$ & Description & Authors & Date & Diffusion \\
\hline PowerPoint & $\begin{array}{l}\text { Xerox's } \\
\text { GHG } \\
\text { Reduction } \\
\text { Initiative }\end{array}$ & $\begin{array}{l}\text { Health and } \\
\text { Safety } \\
\text { and Sus- } \\
\text { tainability } \\
\text { Depart- } \\
\text { ment }\end{array}$ & $\begin{array}{c}2006 \text { and } \\
2010\end{array}$ & $\begin{array}{c}\text { Internal and } \\
\text { external }\end{array}$ \\
\hline $\begin{array}{c}\text { Excel and } \\
\text { internal } \\
\text { software }\end{array}$ & $\begin{array}{l}\text { Environ- } \\
\text { mental } \\
\text { Perfor- } \\
\text { mance } \\
\text { Metric } \\
\text { Report }\end{array}$ & $\begin{array}{l}\text { Health and } \\
\text { Safety } \\
\text { and Sus- } \\
\text { tainability } \\
\text { Depart- } \\
\text { ment }\end{array}$ & 2002-2011 & Internal \\
\hline $\begin{array}{c}\text { Excel and } \\
\text { internal } \\
\text { software }\end{array}$ & $\begin{array}{l}\text { Greenhouse } \\
\text { Gas } \\
\text { Emissions } \\
\text { reporting }\end{array}$ & $\begin{array}{l}\text { Health and } \\
\text { Safety } \\
\text { and Sus- } \\
\text { tainability } \\
\text { Depart- } \\
\text { ment }\end{array}$ & 2002-2011 & Internal \\
\hline Pdf & $\begin{array}{l}\text { EC } 2012 \\
\text { Revision }\end{array}$ & $\begin{array}{l}\text { Health and } \\
\text { Safety } \\
\text { and Sus- } \\
\text { tainability } \\
\text { Depart- } \\
\text { ment }\end{array}$ & 2006 & Internal \\
\hline PowerPoint & $\begin{array}{l}\text { Environ- } \\
\text { ment } \\
\text { Health } \\
\text { and Safety } \\
\text { Seminars }\end{array}$ & $\begin{array}{l}\text { Health and } \\
\text { Safety } \\
\text { and Sus- } \\
\text { tainability } \\
\text { Depart- } \\
\text { ment }\end{array}$ & $\begin{array}{l}2003 \\
2006 \\
2009\end{array}$ & Internal \\
\hline PowerPoint & $\begin{array}{l}\text { Lean Six } \\
\text { Sigma, } \\
\text { Environ- } \\
\text { ment } \\
\text { Modules }\end{array}$ & $\begin{array}{l}\text { Health and } \\
\text { Safety } \\
\text { and Sus- } \\
\text { tainability } \\
\text { Depart- } \\
\text { ment }\end{array}$ & $\begin{array}{l}2006 \\
2011\end{array}$ & Internal \\
\hline
\end{tabular}

\section{Appendix 4: Inventory of Interviewees and Classification}

\begin{tabular}{lll}
\hline Function & Hierarchical position & Duration \\
\hline $\begin{array}{l}\text { Vice president, health, safety, and } \\
\text { sustainability }\end{array}$ & Top manager & $1 \mathrm{~h} 14 \mathrm{~min}$ \\
$\begin{array}{l}\text { Environmental sustainability } \\
\text { program manager }\end{array}$ & Top manager & $1 \mathrm{~h} 24 \mathrm{~min}$ \\
$\begin{array}{l}\text { Environmental project manager of } \\
\text { the EA toner plant (Webster) }\end{array}$ & Middle manager & $1 \mathrm{~h} 21 \mathrm{~min}$ \\
$\begin{array}{l}\text { Energy manager for the Xerox } \\
\quad \text { Webster campus }\end{array}$ & Middle manager & $1 \mathrm{~h} 15 \mathrm{~min}$ \\
$\begin{array}{l}\text { Environmental program manager } \\
\text { in charge of energy reporting }\end{array}$ & Middle managers & $1 \mathrm{~h} 25 \mathrm{~min}$ \\
$\begin{array}{l}\text { Environmental sustainability } \\
\text { manager }\end{array}$ & Top managers & $1 \mathrm{~h} 23 \mathrm{~min}$ \\
\hline
\end{tabular}

\begin{tabular}{lll}
\hline Function & Hierarchical position & Duration \\
\hline $\begin{array}{l}\text { Environmental saving reporting } \\
\text { Environmental engineer focusing } \\
\text { on water }\end{array}$ & Middle manager & $1 \mathrm{~h} 28 \mathrm{~min}$ \\
$\begin{array}{l}\text { Environmental engineer focusing } \\
\text { on air }\end{array}$ & Top manager & $1 \mathrm{~h} 05 \mathrm{~min}$ \\
$\begin{array}{l}\text { Environmental engineer focusing } \\
\text { on air }\end{array}$ & Middle manager & $1 \mathrm{~h} 24 \mathrm{~min}$ \\
\hline
\end{tabular}

\section{References}

Ahrens, T., \& Chapman, C. C. (2004). Accounting for flexibility and efficiency: A field study of management control systems in a restaurant chain. Contemporary Accounting Research, 21(2), 271-301.

Alt, E., Diez-de-Castro, P.-D., \& Lloréns-Montes, F.-J. (2015). Linking employee stakeholders to environmental performance: The role of proactive environmental strategies and shared vision. Journal of Business Ethics, 128(1), 167-181.

Aragon-Correa, J. A., Hurtado-torres, N., Sharma, S., \& GarciaMorales, V. J. (2008). Environmental strategy and performance in small firms: A resource-based perspective. Journal of Environmental Management, 86(1), 88-103.

Aragon-Correa, J. A., \& Sharma, S. (2003). A contingent resourcebased view of proactive corporate environmental strategy. Academy of Management Review, 28(1), 71-88.

Arjaliès, D. L., \& Mundy, J. (2013). The use of management control systems to manage CSR strategy: A levers of control perspective. Management Accounting Research, 24(4), 284-300.

Bamford, D. (2008). The use of grounded theory in change management research. Journal of Change Management, 8(2), 111-121.

Banerjee, S. B., Iyer, E. S., \& Kashyap, R. K. (2003). Corporate environmentalism: Antecedents and influence of industry type. Journal of Marketing, 67(2), 99-120.

Bedford, D. S. (2015). Management control systems across different modes of innovation: Implications for firm performance. Management Accounting Research, 28, 12-30.

Berry, M. A., \& Rondinelli, D. A. (1998). Proactive corporate environmental management: A new industrial revolution. Academy of Management Executive, 12(2), 38-50.

Besio, C., \& Pronzini, A. (2014). Morality, ethics, and values outside and inside organizations: An exemple of the discourse on climate change. Journal of Business Ethics, 119(3), 287-300.

Bisbe, J., \& Malagueno, R. (2009). The choice of interactive control systems under different innovation management tools. European Accounting Review, 18(2), 371-405.

Bisbe, J., \& Otley, D. (2004). The effects of interactive use of management control systems on product innovation. Accounting, Organizations and Society, 29, 709-737.

Boiral, O. (2006). Global warning: Should companies adopt a proactive strategy. Long Range Planning, 39(3), 315-330.

Boiral, O. (2007). Corporate greening through ISO 14001: A rational myth? Organization Science, 1, 127-146.

Bruining, H., Bonnet, M., \& Wright, M. (2004). Management control systems and strategy change in buyouts. Management Accounting Research, 15(2), 155-177.

Chang, C.-H. (2011). The influence of corporate environmental ethics on competitive advantage: The mediation role of green innovation. Journal of Business Ethics, 104(3), 361-370. 
Collins, H. M. (2001). Good to Great. New York: HarperCollins Publisher Inc.

Cooper, D. J., \& Morgan, W. (2008). Case study research in accounting. Accounting Horizons, 22(2), 159-178.

Cordano, M., Marshall, R. S., \& Silverman, M. (2010). How do small and medium enterprises go green? A study of environmental management programs in the U.S. wine industry. Journal of Business Ethics, 92(3), 463-478.

Crowley, C., Harre, R., \& Tagg, C. (2002). Qualitative research and computing: methodological issues and practices in using QSR NVivo and NUD*IST. International Journal of Social Research Methodology, 5(3), 193-197.

Dangelico, R. M., \& Pujari, D. (2010). Mainstreaming green product innovations: Why and how companies integrate environmental sustainability. Journal of Business Ethics, 95, 471-486.

Darnall, N., Seol, I., \& Sarkis, J. (2008). Perceived stakeholder influences and organizations' use of environmental audits. Accounting, Organizations and Society, 34(2), 170-187.

Delgado-Ceballos, J., Aragon-Correa, J.-A., Ortiz-de-Mandojana, N., \& Rueda-Manzanares, A. (2012). The effect of internal barriers and the connection between stakeholder integration and proactive environmental strategies. Journal of Business Ethics, 107(3), 281-293.

Dhanda, K. K., \& Hartman, L. P. (2011). The ethics of carbon neutrality: A critical examination of voluntary carbon offset providers. Journal of Business Ethics, 100(1), 119-149.

Dibrell, C., Craig, J., Kim, J., \& Johnson, A. (2015). Establishing how natural environmental competency, organizational social consciousness, and innovativeness relate. Journal of Business Ethics, 127(3), 591-605.

Dowell, G., Hart, S., \& Yeung, B. (2000). Do corporate global environmental standards create or destroy market value. Management Science, 46(8), 1059-1074.

Eisenhardt, K. M. (1989). Building theories from case study research. Academy of Management Review, 14(4), 532-550.

Glaser, B. G., \& Strauss, A. L. (1967). The discovery of grounded theory: Strategies for qualitative research. New York: Aldine de Gruyter.

Goebel, S., \& WeiBenberger, B. E. (2017). The relationship between informal controls, ethical work climates, and organizational performance. Journal of Business Ethics, 141(3), 505-528.

Gond, J.-P., Grubnic, S., Herzig, C., \& Moon, J. (2012). Configuring management control systems: theorizing the integration of strategy and sustainability. Management Accounting Research, 23(3), 205-223.

Haney, A. B. (2017). Threat interpretation and innovation in the context of climate change: An ethical perspective. Journal of Business Ethics, 143(2), 261-276.

Hart, S. L. (1995). A natural-resource-based view of the firm. Academy of Management Review, 20(4), 996-1014.

Hart, S. L., \& Ahuja, G. (1996). Does it pay to be green? An empirical examination of the relationship between emission reduction and firm performance. Business Strategy and the Environment, $5(1), 30-37$.

Hart, S. L., \& Dowell, G. (2011). A natural-resource-based view of the firm: 15 years after. Journal of Management (Invited Editorial), $37(5), 1464-1479$.

Hartley, J. (2004). Case study research. London: Sage.

Henri, J.-F. (2006). Management control systems and strategy: A resource-based perspective. Accounting, Organizations and Society, 31(6), 529-558.

Henri, J. F., \& Journeault, M. (2010). Eco-Control: The influence of management control systems on environmental and economic performance. Accounting, Organizations and Society, 35(1), 63-80.
Hoffman, K. H., Theyel, G., \& Wood, C. H. (2012). Identifying firm capabilities as drivers of environmental management and sustainability practices-Evidences from small and medium sized manufacturers. Business Strategy and the Environment, 21(8), 530-545.

Holland, D., \& Albrecht, C. (2013). The worldwide academic field of business ethics: Scholars' perceptions of the most important issues. Journal of Business Ethics, 117(4), 777-788.

Huberman, A. M., \& Miles, M. B. (1994). Data management and analysis methods. Handbook of qualitative research. London: N. Denzin and Y. Lincoln.

Hutchinson, C. (1996). Integrating environment policy with business strategy. Long Range Planning, 29(1), 11-23.

Jiang, R. J., \& Bansal, P. (2003). Seeing the need for ISO 14001. Journal of Management Studies, 40(4), 1047-1067.

Jose, A., \& Lee, S. M. (2007). Environmental reporting of global corporations: A content-analysis based on website disclosure. Journal of Business Ethics, 72(4), 307-321.

Journeault, M. (2016). The influence of the eco-control package on environmental and economic performance: A natural resourcebased approach. Journal of Management Accounting Research, 28(2), 149-178.

Journeault, M., De Rongé, Y., \& Henri, J.-F. (2016). Levers of eco-control and competitive environmental strategy. The British Accounting Review, 48(3), 316-340.

Kloot, L. (1997). Organizational learning and management control systems: Responding to environmental change. Management Accounting Research, 8(1), 47-73.

Lannelongue, G., Gonzalez-Benito, O., \& Gonzalez-Benito, J. (2014). Environmental motivations: The pathway to complete environmental management. Journal of Business Ethics, 124(1), 135-147.

Lanoie, P., Laurent-Lucchetti, J., Johnstone, N., \& Ambec, S. (2011). Environmental policy, innovation and performance: New insights on the porter hypothesis. Journal of Economic Management Strategy, 20(3), 803-841.

Lee, T. W. (1999). Using qualitative methods in organizational research. Thousand Oaks, CA: Sage.

Leonidou, L. C., Christodoulides, P., Kyrgidou, L. P., \& Palihawadana, D. (2017). Internal drivers and performance consequences of small firm green business strategy: The moderating role of external forces. Journal of Business Ethics, 140(3), 585-606.

Leonidou, C. N., \& Leonidou, L. C. (2011). Research into environmental marketing/management: A bibliographic analysis. European Journal of Marketing, 45(1/2), 68-103.

Lisi, I. E. (2015). Translating environmental motivations into performance: The role of environmental performance measurement systems. Management Accounting Research, 29(4), 27-44.

Lopez-Gamero, M. D., Claver-Cortes, E., \& Molina-Azonrin, J. F. (2008). Complementary resources and capabilities for an ethical and environmental management: A qual/quan study. Journal of Business Ethics, 82(3), 701-732.

Lovins, A. B., Hunter Lovins, L., \& Hawken, P. (1999). A road map for natural capitalism. Harvard Business Review, 77(3), 145-158.

Lueg, R., \& Radlach, R. (2016). Managing sustainable development with management control systems: A literature review. European Management Journal, 34(2), 158-171.

Maignan, I., \& Ralston, D. A. (2002). Corporate social responsibility in Europe and the U.S.: Insights from businesses' self-presentations. Journal of International Business Studies, 33(3), 497-514.

Menguc, B., Auh, S., \& Ozanne, L. K. (2010). The interactive effect of internal and external factors on a proactive environmental strategy and its influence on a firm's performance. Journal of Business Ethics, 94(2), 279-298.

Merton, R. K., Fiske, M., \& Kendall, P. L. (1990). The focused interview: A manual of problems and procedures (2nd ed.). New York: Free Press. 
Miles, M. B., \& Huberman, A. M. (1994). Qualitative data analysis (2nd ed.). Thousand Oaks, CA: Sage Publication.

Molloy, J. C., Chadwick, C., Ployhart, R. E., \& Golden, S. J. (2011). Making intangibles "tangibles" in test of resource-based theory: A multidisciplinary construct validation approach. Journal of Management, 37(5), 1496-1518.

Nilsson, F. (2002). Recent advances in performance management: The nordic case. European Management Journal, 20(3), 235-246.

O'Reilly, K., Paper, D., \& Marx, S. (2012). Demystifying grounded theory for business research. Organizational Research Methods, 15(2), 247-262.

Perez, E. A., Correa Ruiz, C., \& Carrasco Fenech, F. (2007). Environmental management systems as an embedding mechanism: A research note. Accounting, Auditing \& Accountability Journal, 20(3), 403-422.

Porter, M. E., \& van der Linde, C. (1995). Green and competitive: Ending the stalemate. Harvard Business Review, 73(5), 120-134.

Ramus, C. A., \& Steger, U. (2000). The role of supervisory support behaviours and environmental policy in employee 'ecoinitiatives' at leading-edge European companies. Academy of Management Journal, 43(4), 605-626.

Revell, A., Stokes, D., \& Chen, H. (2010). Small business and the environment: Turning over a new leaf? Business Strategy and the Environment, 19(5), 273-288.

Russo, M. V., \& Fouts, P. A. (1997). A resource-based perspective on corporate environmental performance and profitability. Academy of Management Journal, 40(3), 534-559.

Scott, W. R. (2001). Institutions and organizations. Thousand Oaks: Sage Publication.

Shapiro, B. (2016). Using traditional narratives and other narrative devices to enact humanizing business practices. Journal of Business Ethics, 139(1), 1-19.

Sharma, S., Aragon-Correa, J.-A., \& Rueda-Manzanares, A. (2007). The contingent influence of organizational capabilities on proactive environmental strategy in the service sector: An analysis of North American and European Ski Resorts. Canadian Journal of Administrative Sciences, 24(4), 268-283.
Sharma, S., \& Vredenburg, H. (1998). Proactive corporate environmental strategy and the development of competitively valuable organizational capabilities. Strategic Management Journal, 19(8), 729-753.

Shrivastava, P. (1995). Environmental technologies and competitive advantage. Strategic Management Journal, 16, 183-200.

Simons, R. (1990). The role of management control systems in creating competitive advantage: New perspectives. Organizations and Society, 15(1/2), 127-143.

Simons, R. (1995). Levers of control: How managers use innovative control systems to drive strategic renewal. Boston: Harvard Business School Press.

Simons, R. (2000). Performance measurement and control systems for implementing strategy. New Jersey, NJ: Prentice-Hall.

Snider, J., Hill, R. P., \& Martin, D. (2003). Corporate social responsibility in the 21st century: A view from the world's most successful firms. Journal of Business Ethics, 48(2), 175-187.

Tucker, B., Thorne, H., \& Gurd, B. (2009). Management control and strategy: What's been happening? Journal of Accounting Literature, 28(1), 123-163.

Welsh, E. (2002). Dealing with data: Using NVivo in the qualitative data analysis process. Forum: Qualitative Social Research, 3(2), 26.

Williamson, D., Lynch-Wood, G., \& Ramsay, J. (2006). Drivers of environmental behavior in manufacturing SMEs and the implications for CSR. Journal of Business Ethics, 67(3), 317-330.

Worthington, I., \& Patton, D. (2005). Strategic Intent in the management of the green environment within SMEs. Long Range Planning, 38(2), 197-212.

Yin, R. K. (2003). Case study research: Design and methods (3rd ed.). Thousand Oaks, CA: Sage.

Yin, R. K. (2009). Case study research: Design and methods (4th ed.). CA: Sage Thousand Oaks. 